\title{
Quantity and quality of potato yield as influenced by unbalanced and excessive fertilization
}

\author{
MARKKU YLI-HALLA, ESKO VIIKARI and JUHA PALONEN \\ Kemira Oy, Espoo Research Centre, Luoteisrinne 2 \\ SF-02270 ESPOO, Finland
}

\begin{abstract}
Potato (var. Rekord) was cultivated for three years in a sandy field. It was given various levels of three fertilizers the $\mathrm{N}, \mathrm{P}$ and $\mathrm{K}$ composition of which in percentages was 7-11-12, 18-3-12 and 27.5-0-0. The $\mathrm{N}$ levels were $0,80 / 60,140 / 120$ and $300 / 240 \mathrm{~kg} / \mathrm{ha}(1983 / 1984-85)$, but the $\mathrm{P}$ and $\mathrm{K}$ levels varied according to the composition of the fertilizers. In the first year the yields were high regardless of fertilization. The following years the yields were clearly highest in the plots where the fertilizer 7-11-12 was used. This was due to insufficient $\mathrm{P}$ and $\mathrm{K}$ supply in the other plots. With increasing $\mathrm{N}$ fertilization the starch content and mealiness of the tubers decreased and the flavour was degraded. The two higher $\mathrm{N}$ levels yielded a considerably higher nitrate content than was measured in tubers from unfertilized plots and those receiving the lowest levels of fertilizers. The present results point out the significance of appropriate $\mathrm{N}$ fertilization for potato. A certain $\mathrm{N}$ amount was necessary to produce a quantitatively satisfactory yield but excessive amounts had an adverse effect on the quality. $\mathrm{P}$ and $\mathrm{K}$ were of minor importance for the quality in this experiment, but abundant $\mathrm{P}$ and $\mathrm{K}$ fertilization was needed for optimum yield formation. Maintenance of soil $\mathrm{K}$ level proved difficult in continuous potato cultivation.
\end{abstract}

Index words: mealiness, flavour, starch content, nitrate content, soil fertility

\section{Introduction}

Recently, the unsatisfactory quality of table potato has been a topic frequently discussed in Finland. Investigations of the National Board of Trade and Consumer Interests have revealed that in 1983 about $30 \%$ of the potato bags available in shops did not fulfil the quality requirements set for table potato (ANON. 1984). The degraded quality of potato has often been attributed to changes in potato cultivation during the last two decades: In Finland, a great deal of potato is grown in specialized farms with insufficient field area for proper crop rotation. Fertilization has also been blamed. An opposite point of view is the improper handling and storage.

The primary purpose of this three-year experiment was to study the response of potato quality to unbalanced and excessive fertiliza- 
Table 1. Quantities of $\mathrm{N}, \mathrm{P}$ and $\mathrm{K}(\mathrm{kg} / \mathrm{ha})$ applied in various fertilizer treatments.

\begin{tabular}{|c|c|c|c|c|c|c|c|}
\hline \multirow{2}{*}{$\begin{array}{l}\text { Fertilizer and } \\
\text { fertilization level }\end{array}$} & & \multicolumn{2}{|c|}{$\mathrm{N}$} & \multicolumn{2}{|c|}{$\mathrm{P}$} & \multicolumn{2}{|c|}{ K } \\
\hline & & 1983 & $1984-85$ & 1983 & $1984-85$ & 1983 & $1984-85$ \\
\hline $7-11-12$ & I & 80 & 60 & 126 & 94 & 137 & 103 \\
\hline " & II & 140 & 120 & 220 & 188 & 240 & 206 \\
\hline$"$ & III & 300 & 240 & 471 & 376 & 514 & 410 \\
\hline $18-3-12$ & I & 80 & 60 & 13 & 10 & 53 & 40 \\
\hline$"$ & II & 140 & 120 & 23 & 20 & 93 & 80 \\
\hline$"$ & III & 300 & 240 & 50 & 40 & 200 & 160 \\
\hline $27.5-0-0$ & I & 80 & 60 & - & - & - & - \\
\hline " & II & 140 & 120 & - & - & - & - \\
\hline$"$ & III & 300 & 240 & - & - & - & - \\
\hline
\end{tabular}

tion. The quality was assessed by measuring parameters expressing the chemical composition of the tubers as well as by grading the mealiness and flavour of cooked potatoes. Yields and changes in the nutrient content of the soil were also evaluated.

\section{Materials and methods}

The experiment was made at Kotkaniemi experimental farm in Vihti, Southern Finland, on three consecutive summers from 1983 to 1985. The field was sandy, $92 \%$ of the soil material being coarser than $0.06 \mathrm{~mm}$ in diameter and the soil contained $0.9 \%$ organic carbon. In 1982, spring wheat was grown in the same field.

Three levels of three fertilizers, designated in this paper according to their $\mathrm{N}, \mathrm{P}$ and $\mathrm{K}$ contents in percentages, were applied. Fertilizer 7-11-12 is specially designed for table potato. It contains $\mathrm{K}$ as $\mathrm{K}_{2} \mathrm{SO}_{4}$. Fertilizer 18-3-12 contains $\mathrm{K}$ as $\mathrm{KCl}$ and $27.5-0-0$ only $\mathrm{N}$. The fertilizer levels corresponded to certain $\mathrm{N}$ levels, but the amounts of $\mathrm{P}$ and $\mathrm{K}$ varied (Table 1). In 1983, the $\mathrm{N}$ levels were 80,140 and $300 \mathrm{~kg} / \mathrm{ha}$, in the following years 60,120 and $240 \mathrm{~kg} / \mathrm{ha}$. To provide a reference sample, potato was grown also with no fertilization. In addition, $95 \mathrm{~kg} \mathrm{Mg}$ as $\mathrm{MgSO}_{4}$ was applied in 1983 and 1985.

Each spring the field was harrowed lightly, fertilizers were broadcasted and ploughed in and the field was harrowed. The seed tubers of the variety Record, sprouted for two weeks, were planted $28-30 \mathrm{~cm}$ apart using an automatic two-row machine. Each plot, sized $2.8 \mathrm{~m} \times 10 \mathrm{~m}$, consisted of four rows. The experiment was arranged in four randomized blocks. The same plots were used yearly to find out the cumulative effect of fertilization. The potatoes were harvested with a two-row digger. The dates of planting and harvest as well as the growing time were as follows:

$\begin{array}{llll} & \text { planting } & \text { harvest } & \text { growing time } \\ 1983 & \text { May, 19 } & \text { Sept., 9 } & 118 \mathrm{~d} . \\ 1984 & \text { May, 23 } & \text { Sept., 6 } & 106 \mathrm{~d} . \\ 1985 & \text { June, 6 } & \text { Sept., 23 } & 110 \mathrm{~d} \text {. }\end{array}$

The yield of the two middle rows of each plot was weighed and the tubers were divided into three size fractions: smaller than $25 \mathrm{~mm}$, $25-55 \mathrm{~mm}$ and larger than $55 \mathrm{~mm}$. These fractions were also weighed separately. The potatoes of the middle size fraction were analyzed for starch by weighing in water and in the air at Hämeen Peruna Oy. In 1983, also nitrate nitrogen and ascorbic acid (vitamin C) were determined. Nitrate was extracted with water and ascorbic acid with a mixture of acetonitrile and water $(1: 1 \mathrm{v} / \mathrm{v})$. The measurements were done by liquid chromatography. The cooking quality of the middle size fraction was evaluated by grading the tubers for flavour and mealiness. The rating of LuGT and Goodısk (1959, ref. Ellala et al. 1971) as modified by ElLaLa et al. (1971) was used. 
Table 2. Total potato yields ( $\mathrm{t} / \mathrm{ha}$ ) and percentages of various tuber size fractions.*

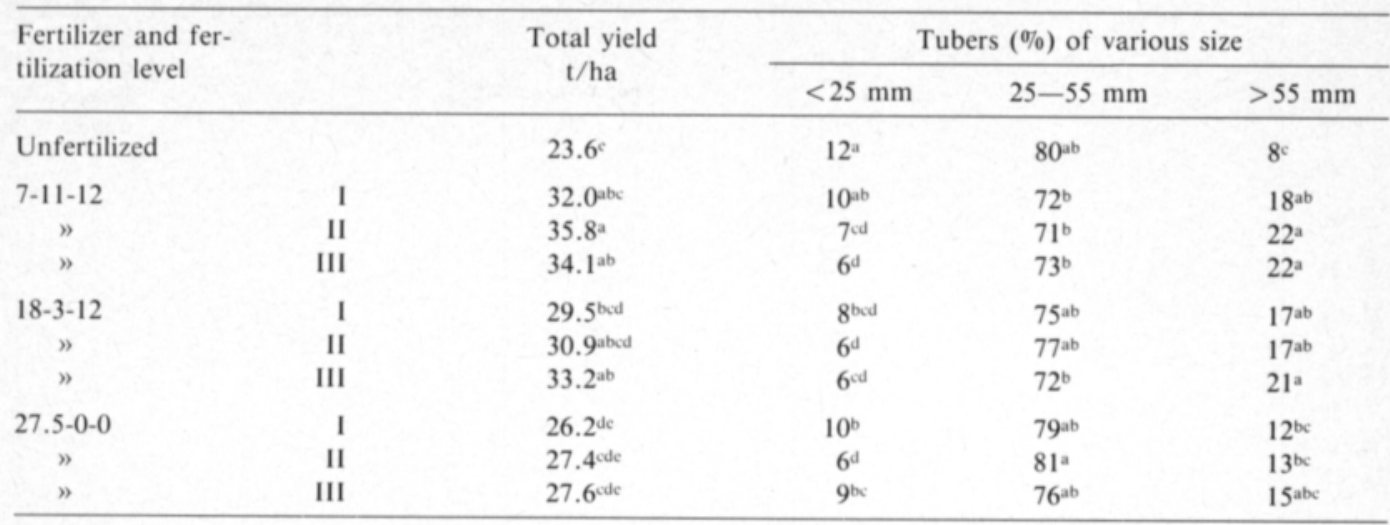

* Each column has been tested separately. Means marked with a common letter do not differ at $\mathrm{P}=0.05$.

This rating, using scores from 1 to 4 , was done by the same six trained examiners every year in October-November. Soil samples were taken at the beginning of the experiment from each block and after the trial from each plot. The samples were analyzed for $\mathrm{P}, \mathrm{K}$ and $\mathrm{Ca}$ according to VUORINEN and MÄKITIE (1955). The results for mealiness and flavour were tested statistically with Wilson's non-parametric analysis of variance (WILSON 1956) and other results with the common analysis of variance and with Student-Neuman-Keuls' test as well as with correlation analysis (STEEL and TORRIE 1980).

\section{Results}

\section{Yields}

The tuber yields are presented in Table 2. Compared with the unfertilized yields, increases of $36 \%, 25 \%$ and $11 \%$ were obtained by the lowest levels of the fertilizers 7-11-12, 18-3-12 and 27.5-0-0, respectively. There was a slight but statistically insignificant tendency of the yields to increase as the dose of a certain fertilizer was elevated to the second level and, in case of the fertilizer 18-3-12, further to the highest one.

The yield of the size fraction $25-55 \mathrm{~mm}$ correlated closely $\left(\mathrm{r}=0.92^{* * *}\right)$ with the total yield and averaged $76 \%$ of it. The percentage of small tubers was highest in the unfertilized plots (Table 2). The percentage of the large tubers $(>55 \mathrm{~mm})$ increased slightly with increasing fertilizer level.

The yields decreased sharply from year to year, the overall averages of the experiment in various years being as follows:

$\begin{array}{ll}1983 & 40.6 \mathrm{t} / \mathrm{ha} \\ 1984 & 30.6 " \\ 1985 & 18.4 ”\end{array}$

Besides unbalanced fertilization, the decrease may partly be due to the weather which in 1983 was very favourable for potato with an even distribution of precipitation and a rather high temperature. The two latter years were colder with excessive rains in July or August. In addition, in 1985 the low yields can also be attributed to seed tubers infected by Erwinia carotovora.

In 1983, there were only small differences between the yields of the various fertilization treatments (Fig. 1). Even the unfertilized plots yielded as much as $28.1 \mathrm{t} / \mathrm{ha}$. In the following years the differences widened, and in 1984 and 1985 the fertilizer 7-11-12 produced considerably higher yields than did the other ones.

\section{Chemical composition of the yield}

The content of starch ranged from $11.1 \%$ to $17.9 \%$, mean $15.2 \%$. The unfertilized 
Fertilizer 7-11-12

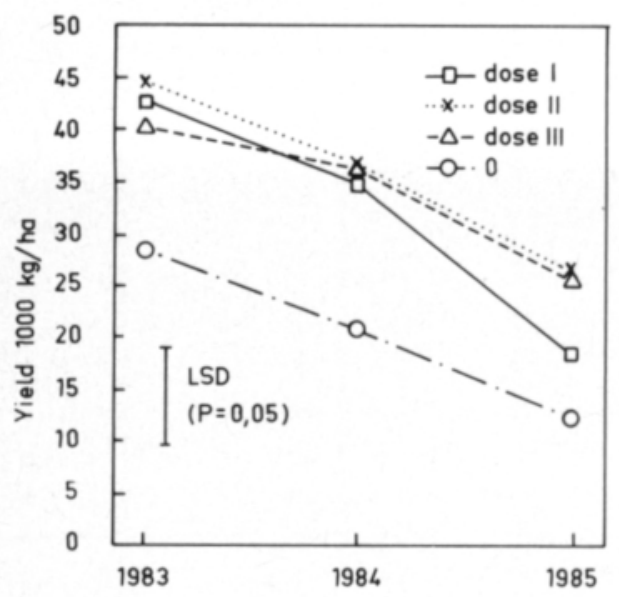

Fertilizer 27,5-0-0

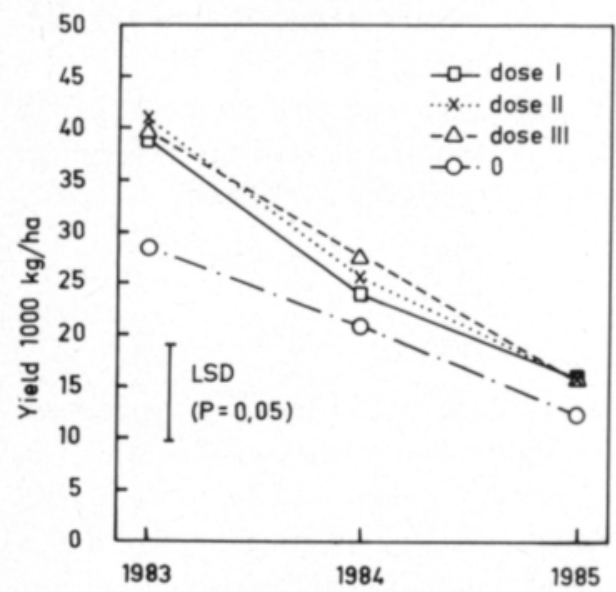

Fertilizer $18-3-12$
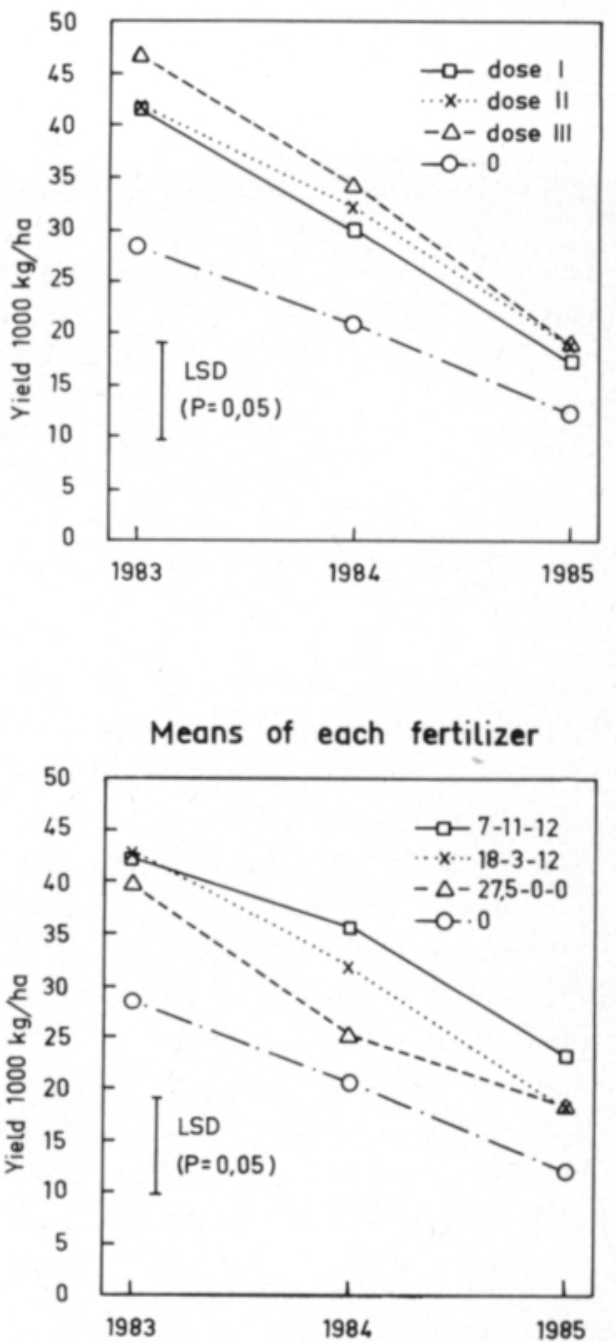

Fig. 1. Potato yields obtained from plots fertilized with various doses of three fertilizers in three years.

potatoes exhibited the highest starch content, mean $16.5 \%$. The fertilizer $27.5-0-0$ produced tubers higher in starch content $(15.9 \%)$ than did the two NPK fertilizers $(14.7 \%)$. The starch content decreased with increasing fertilization and correlated closely with starch yields $\left(\mathrm{r}=0.98^{* * *}\right)$ (Table 3$)$.

Fertilization had a major influence on the $\mathrm{NO}_{3}-\mathrm{N}$ content of the tubers. Despite the great variation between the blocks there was a clear tendency of $\mathrm{NO}_{3}-\mathrm{N}$ content to grow three-to-sixfold as the fertilization was increased from N $80 \mathrm{~kg} /$ ha to $\mathrm{N} 300 \mathrm{~kg} / \mathrm{ha}$. The nitrate content was, however, equal in tubers fertilized with $80 \mathrm{~kg} \mathrm{~N} / \mathrm{ha}$ and those not fertilized at all. The vitamin $\mathrm{C}$ content was highest in the unfertilized tubers and lowest in those given the highest levels of NPK fertilizers.

\section{Mealiness and flavour}

The average scores given to cooked potatoes (Table 4) were the lower the larger quantities of fertilizers had been applied. The fertilization rate had a statistically significant effect $\left({ }^{* * *}\right)$ on the mealiness and flavour, but the 
Table 3. Content of starch $(\%)(1983-1985)$, nitrate nitrogen $(\mathrm{mg} / \mathrm{kg})(1983)$ and vitamin $\mathrm{C}(\mathrm{mg} /$ $100 \mathrm{~g})(1983)$ in fresh potato.*

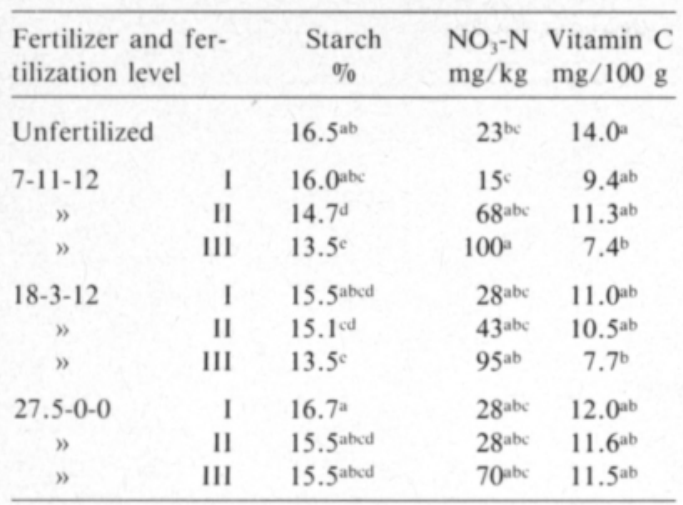

* Each column has been tested separately.

variation between the years was not significant. The scores given to these two properties correlated with each other $\left(r=0.62^{* * *}\right)$. The scores given to unfertilized potatoes and to potatoes receiving the lowest level exceeded usually 2.5 , which is the minimum requirement for table potato according to ElLALA et al. (1971). The plots receiving higher levels of fertilizers produced tubers of inferior mealiness and flavour with only few exceptions.

The scores given by various examiners were studied with correlation analysis (Table 5). The correlation coefficients between the scores for mealiness were considerably higher than those for flavour. The scores given by the examiner number five were systematically lower than those given by the others.

\section{Soil analyses}

The various fertilizer treatments had caused considerable changes in soil fertility parameters (Table 6). The soil $\mathrm{pH}$ had decreased slightly, the more the higher levels of fertilizers had been applied. The amount of exchangeable $\mathrm{Ca}$ had decreased consequently. The amount of exchangeable $\mathrm{K}$ had decreased in all plots except in those receiving the highest level of the fertilizers 7-11-12 and 18-3-12. Soil $P$ was the higher the more $\mathrm{P}$ fertilization had been given. Despite the excessive fertilizer levels given to certain plots, the electrical conductivity reflecting the salt content of the soil solution was practically equally low in all plots. This shows that ions not taken up by the crop and not sorbed by the soil (mainly nitrate, sulphate and chloride) had leached from the soil. The leaching had probably occurred mainly with soil $\mathrm{Ca}$ the amount of which had decreased most in the plots receiving the highest amounts of fertilizers.

\section{Discussion}

A potato crop of $30 \mathrm{t} /$ ha contains N $120-$ $140 \mathrm{~kg} / \mathrm{ha}, \mathrm{P} 15-20 \mathrm{~kg} / \mathrm{ha}$ and $\mathrm{K} 190-$ $240 \mathrm{~kg} / \mathrm{ha}$ (VARIS $1973 \mathrm{a}$ ). Despite the rather

Table 4. Scores given to mealiness and flavour by the examiner group.

\begin{tabular}{|c|c|c|c|c|c|c|c|c|c|c|}
\hline \multirow[t]{3}{*}{ Year } & \multicolumn{10}{|c|}{ Scores given to treatments } \\
\hline & \multirow{2}{*}{$\begin{array}{l}\text { Unferti- } \\
\text { lized }\end{array}$} & \multicolumn{3}{|c|}{$7-11-12$} & \multicolumn{3}{|c|}{$18-3-12$} & \multicolumn{3}{|c|}{$27.5-0-0$} \\
\hline & & I & II & III & I & II & III & I & II & III \\
\hline \multicolumn{11}{|c|}{ Flavour } \\
\hline 1983 & 2.9 & 2.7 & 2.4 & 2.2 & 2.5 & 2.3 & 2.1 & 2.6 & 2.3 & 2.4 \\
\hline 1984 & 2.8 & 2.8 & 2.4 & 1.9 & 2.5 & 2.5 & 2.1 & 2.7 & 2.3 & 2.5 \\
\hline 1985 & 2.8 & 2.4 & 2.4 & 2.2 & 2.6 & 2.2 & 2.1 & 2.8 & 2.2 & 2.4 \\
\hline Mean & 2.8 & 2.7 & 2.4 & 2.1 & 2.6 & 2.3 & 2.1 & 2.7 & 2.2 & 2.4 \\
\hline \multicolumn{11}{|c|}{ Mealiness } \\
\hline 1983 & 3.1 & 2.6 & 2.3 & 2.1 & 2.7 & 2.2 & 2.1 & 2.8 & 2.6 & 2.4 \\
\hline 1984 & 3.0 & 2.8 & 2.2 & 1.9 & 2.6 & 2.3 & 2.1 & 2.8 & 2.4 & 2.3 \\
\hline 1985 & 2.8 & 2.4 & 2.3 & 2.3 & 2.5 & 2.2 & 2.1 & 2.8 & 2.2 & 2.3 \\
\hline Mean & 3.0 & 2.6 & 2.3 & 2.1 & 2.6 & 2.2 & 2.1 & 2.7 & 2.4 & 2.4 \\
\hline
\end{tabular}


Table 5. Linear correlation coefficients between scores given by various examiners to flavour and mealiness of cooked potatoes as well as overall means of scores.

\begin{tabular}{|c|c|c|c|c|c|c|}
\hline \multirow{2}{*}{$\begin{array}{l}\text { Exami- } \\
\text { ner }\end{array}$} & \multirow[t]{2}{*}{ Mean } & \multicolumn{5}{|c|}{ Examiner } \\
\hline & & 2 & 3 & 4 & 5 & 6 \\
\hline \multicolumn{7}{|c|}{ Flavour } \\
\hline 1 & 2.7 & $0.26^{* *}$ & $0.25 * *$ & $0.28^{* *}$ & $0.40^{* * *}$ & $0.46^{* * *}$ \\
\hline 2 & 2.6 & 1.00 & $0.16^{\text {n.s. }}$ & $0.37 * * *$ & $0.28^{* *}$ & $0.33^{* * *}$ \\
\hline 3 & 2.4 & & 1.00 & $0.25^{* *}$ & $0.30^{* *}$ & $0.40^{* * *}$ \\
\hline 4 & 2.4 & & & 1.00 & $0.37^{* * *}$ & $0.25^{* *}$ \\
\hline 5 & 2.2 & & & & 1.00 & $0.53^{* * *}$ \\
\hline 6 & 2.4 & & & & & 1.00 \\
\hline \multicolumn{7}{|c|}{ Mealiness } \\
\hline 1 & 2.6 & $0.48^{* * *}$ & $0.43^{* * *}$ & $0.55^{* * *}$ & $0.55^{* * *}$ & $0.65^{* * *}$ \\
\hline 2 & 2.6 & 1.00 & $0.28^{* *}$ & $0.48^{* * *}$ & $0.42^{* * *}$ & $0.63^{* * *}$ \\
\hline 3 & 2.5 & & 1.00 & $0.51^{* * *}$ & $0.47^{* * *}$ & $0.61^{* * *}$ \\
\hline 4 & 2.3 & & & 1.00 & $0.45^{* * *}$ & $0.58^{* * *}$ \\
\hline 5 & 2.2 & & & & 1.00 & $0.67^{* * *}$ \\
\hline 6 & 2.4 & & & & & 1.00 \\
\hline
\end{tabular}

Table 6. Soil properties of potato field before and after the experiment.*

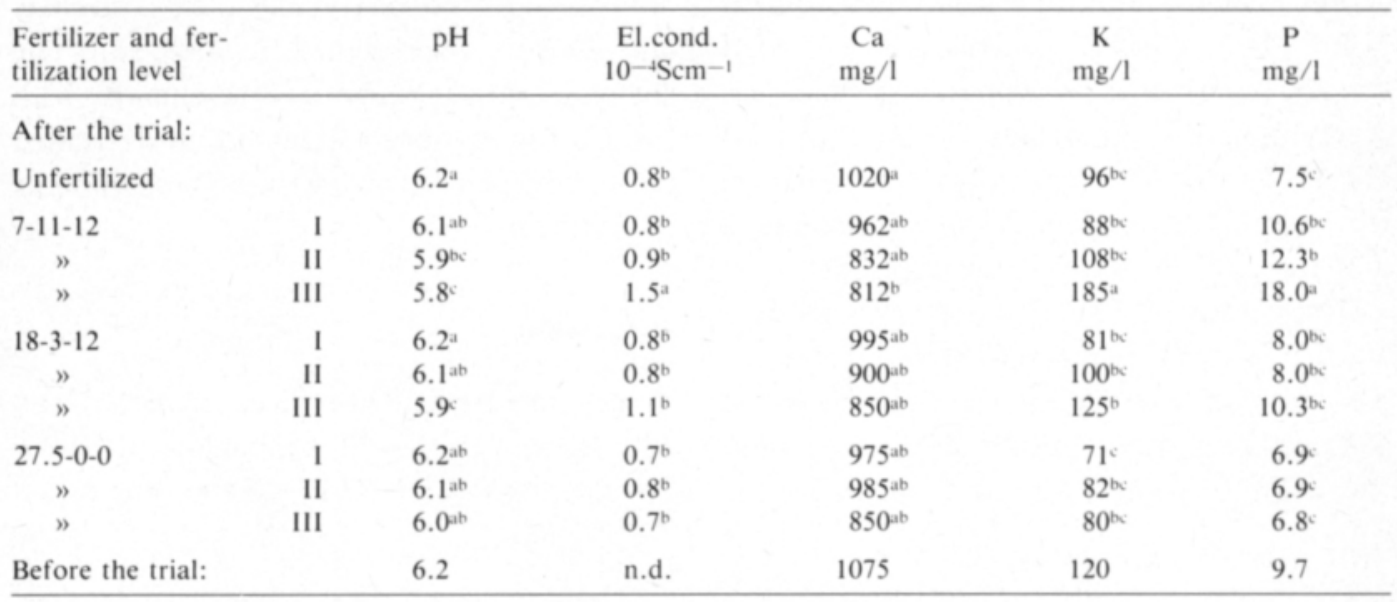

* Each column, omitting the values before the trial, was tested separately.

n.d. = not determined

low $\mathrm{P}$ uptake, the potato crop usually responds to high $\mathrm{P}$ doses up to $130 \mathrm{~kg} / \mathrm{ha}$. The $\mathrm{P}$ and $\mathrm{K}$ requirement of potato was in this experiment satisfied only with the fertilizer 7-11-12, particularly designed for table potato. Despite a very unbalanced fertilization in certain plots, rather high yields were obtained in 1983 from all plots with only small differences between the fertilizer treatments, because the crop utilized the soil reserves of $\mathrm{P}$ and $\mathrm{K}$. In the following years, the nutrient reserves of soil, especially those of $\mathrm{K}$, were exhausted in the coarse soil. In the plots receiving the fertilizers 18-3-12 and 27.5-0-0 it was the supply of P and $\mathrm{K}$ which in the latter years had obviously limited the yield formation. Even the lowest level of the fertilizer 7-11-12 in which 103 or $137 \mathrm{~kg} \mathrm{~K} / \mathrm{ha}$ was applied could not prevent the depletion of soil $\mathrm{K}$ reserves. Only the highest level of that fertilizer elevated the amount of exchangeable $\mathrm{K}$ in the soil. On the contrary, the level of easily soluble $\mathrm{P}$ was 
much more easily maintained. $\mathrm{N}$ fertilization of $100 \mathrm{~kg} / \mathrm{ha}$ and $110 \mathrm{~kg} / \mathrm{ha}$ have produced the highest yields in the factorial experiments of VARIS (1973 a) and TÄHTINEN (1977), respectively. In the present trial, the maximum yield obtained with the fertilizer 7-11-12 was reached at the second fertilization level with the $\mathrm{N}$ level of $140 / 120 \mathrm{~kg} / \mathrm{ha}$. This result may partly be due to the simultaneous increment of $\mathrm{K}$ the quantity of which may not have been sufficient at the lowest level of the fertilizer 7-11-12. Yet, the yield increase attributable to the increment of the fertilization from the first to the second level was small. The experimental design used did not allow detailed evaluation of the influence of single nutrients.

The evaluation of mealiness and flavour of cooked potatoes is dependent on the personal appreciations of the examiners, and the standardization of the scale is therefore difficult. In the present experiment, the examiners were obviously more in agreement about the mealiness than they were about the flavour. Further, mealiness is closely correlated with starch content (VARIS 1970 a), but flavour is not so clearly connected with easily detectable chemical characteristics. This may make mealiness a more reliable measure for the quality of table potato than is flavour.

The scores of mealiness and flavour were the lower the more $\mathrm{N}$ had been applied to the plots and not at all dependent on the doses of $\mathrm{P}$ and $\mathrm{K}$ given. Although comparison of the absolute scores given by different examiner groups is somewhat questionable, the investigation of the trends found in other studies is well justified. The lowering of scores of flavour and mealiness due to increased $\mathrm{N}$ fertilization has earlier been reported by e.g. VARIS (1970 a and b, 1973 b). Also Ellala et al. (1971) noticed that the flavour and mealiness of potato were decreased as an NPK dose twice the recommended one was applied. On the contrary, the remarkable observation that the scores given were not dependent on the doses of $\mathrm{P}$ and $\mathrm{K}$ apparently disagrees with numerous papers. HaHLin and JoHansSON (1973) reported that $\mathrm{P}$ fertilization im- proved the flavour. VARIS (1973 b) made a similar observation about $\mathrm{P}$ fertilization and mealiness. In addition, the disadvantageous effects of $\mathrm{Cl}$ on the quality, applied as $\mathrm{KCl}$ in the fertilizer 18-3-12, were not displayed. Compared with $\mathrm{K}_{2} \mathrm{SO}_{4}, \mathrm{KCl}$ should decrease mealiness (VARIS 1970 b, BLACK and WhITE 1973) and flavour (HAHLIN and JOHANSSON 1973). On the other hand, the blackening of cooked potatoes which is a major disadvantage of $\mathrm{Cl}$ was not determined in the present study.

The above anomalies in the response of mealiness and flavour to fertilization can partly be explained by the differences in starch content of the tubers. Excessive $\mathrm{N}$ fertilization was associated with low starch content which is an indication of delayed maturation, a phenomenon frequently presented in the literature (e.g. VARIS 1973 a). Now, for some reason, the starch content and thus the scores given were constant on a certain $\mathrm{N}$ level regardless of the fertilizer used. The favourable effect of P and the adverse effect of K (VARIS 1973 a) on the starch content could not be distinguished at the lowest level of fertilization, probably due to the small amounts of $\mathrm{P}$ and $\mathrm{K}$, not exceeding the physiological requirement of the crop. Also the quantity of chlorine was small in the lowest dose of the fertilizer 18-3-12. When the fertilization was increased the disadvantageous effect of excessive $\mathrm{N}$ seemed to overrule and it may have masked the other influences.

Besides the lowering of starch content, too high $\mathrm{N}$ doses also strongly elevated nitrate concentrations in the tubers. This shows that potato could not process nitrate nitrogen into ammonium as effectively as $\mathrm{N}$ had been taken up at the higher $\mathrm{N}$ levels. A high nitrate content may also reflect the unmaturation of tubers. The nitrate contents of the potato fertilized with the lowest fertilizer doses were in agreement with the study of MÄKÄrÄINEN (1984) which was based on 303 potato samples. Further, CARTEr and Bosma (1974) showed that the nitrate content of the tubers increased steadily with increasing $\mathrm{N}$ fertilization. The highest concentration reported by them was 
$130 \mathrm{mg} / \mathrm{kg}$ which is near the maximum of this study.

The present results point out the importance of appropriate $\mathrm{N}$ fertilization for table potato. A certain $\mathrm{N}$ dose is needed to produce an economically satisfactory yield, but the quality of potato seems to be detrimentally influenced by excessive amounts. The quality was obviously not equally sensitive to the unbalances

\section{References}

ANON. 1984. Ruokaperunan laadunvalvonta syksyllä 1983. Elinkeinohallitus. Kuluttaja-asiainosaston julk. A 5/84. 16 p. [Quality control of table potato in autumn 1983. Nat. Board Trade Consumer Interests, Publ. Dept. Consumer Aff. A 5/84.]

BLACK, W.N. \& White, R.P. 1973. Effects of nitrogen, phosphorus, potassium and manure factorially applied to potatoes in a long-term study. Can. J. Soil Sci. 53: $205-211$.

Carter, J.N. \& Bosma, S.M. 1974. Effect of fertilizer and irrigation on $\mathrm{NO}_{3}-\mathrm{N}$ and tot. $\mathrm{N}$ in potato tubers. Agron. J. 66: 263-266.

Ellala, A., Vanhanen, L. \& Kurkela, R. 1971. Typpija kalilannoituksen vaikutus ruokaperunan laatuun. Abstract: The influence of nitrogen and potassium fertilizing on the specific gravity and cooking quality of potato varieties Bintje and Realta. J. Scient. Agric. Soc. Finl. 43: 67-72.

Hahlin, M. \& Johansson, O. 1973. Fosfor- och kaliumgödsling till matpotatis. Summary: Phosphorus and potassium fertilization to food potatoes. Lantbrukshögsk. medd. A 192. 47 p. Uppsala.

MÁkÁrÁınen, E. 1984. Suomalaisen ruokaperunan nitraattipitoisuus. Elinkeinohallitus. Kuluttaja-asiainosaston julk. A 6/84. 87 p. [Nitrate content of Finnish table potato. Nat Board Trade Consumer Interests, Publ.

\section{SELOSTUS}

\section{Epätasapainoisen ja liiallisen lannoituksen vaikutus perunasadon määrään ja laatuun}

\author{
Markku Yli-Halla, Esko Viikari ja \\ Juha Palonen
}

Kemira Oy, Espoon tutkimuskeskus 02271 Espoo

Rekord-perunaa viljeltiin karkealla hietamaalla kolmen vuoden ajan ja sitä lannoitettiin Kloorivapaalla Y-lan- in $\mathrm{P}$ and $\mathrm{K}$ nutrition, which supports the observations made by VARIS (1973 b). Abundant $\mathrm{P}$ and $\mathrm{K}$ fertilization was, however, extremely important in maintaining the soil fertility and thus the quantity of the yield.

Acknowledgement. The authors wish to thank Mr. Börje Björkqvist, M.Sc., for determination of nitrate and vitamin C and Mrs. Eija Saarikko, B.Sc., for practical assistance.

Dept. Consumer Aff. A 6/84.]

Steel, R.G.D. \& Torrie, J.H. 1980. Principles and procedures of statistics. 634 p. 2nd Ed. Tokyo.

TÁhtinen, H. 1977. Perunan typpi- ja kaliumlannoitus. Maatalouden tutkimuskeskus. Maanviljelyskemian ja -fysiikan laitos. Tiedote n:o 5. 21 p. [Nitrogen and potassium fertilization of potato. Agric. Res. Centre, Dept. Agric. Chem. Phys. Information sheet no. 5].

VARIS, E. 1970 a. Starch content as a criterion of the cooking quality of potato lots grown under various conditions. Acta Agric. Fenn. 118: 2: 1-26.

,$- 1970 \mathrm{~b}$. Variation in the quality of table potato and the factors influencing it in Finland. Acta Agric. Fenn. 118: 3: 1-79.

—, 1973 a. The effects of increasing NPK rates of the yield and quality of Pito-potato. I. Tuber yield, starch content and starch yield. Acta Agric. Fenn. 128: 1: $1-20$.

-, 1973 b. II. External and internal quality. Acta Agric. Fenn. 128: 2: 1-23.

Vuorinen, J. \& MÁitie, O. 1955. The method of soil testing in use in Finland. Agrogeol. Publ. 63: 1-44.

Wuson, K.V. 1956. A distribution-free test of analyses of variance hypotheses. Physiol. Bull. 53: 96-101.

Ms received June 16, 1987. noksella (lyh. Ykv) (N $7 \%$, P $11 \%$, K $12 \%)$, Oulun typpirikkaalla Y-lannoksella (lyh. OTR) (N $18 \%$, P $3 \%$, 
K $12 \%$ ) ja Oulunsalpietarilla (lyh. OS) (N $27.5 \%$ ). $\mathrm{N}$-lannoitustasot olivat $0,80 / 60,140 / 120$ tai $300 / 240 \mathrm{~kg} /$ ha (1983/1984-85), mutta P- ja K-määrăt vaihtelivat lannoitteen koostumuksen mukaan. Ensimmäisenă vuonna satoerot olivat pieniä mutta maan $\mathrm{P}$ - ja K-varojen ehtyessä toisena ja kolmantena vuonna OTR:n ja OS:n avulla tuotetut sadot jäivăt määrällisesti paljon alle Ykv:lla saatujen satojen. N-lannoituksen kohotessa sadon tärkkelys- pitoisuus pieneni, jauhoisuus aleni ja maku huononi. Kahdella korkeimmalla $\mathrm{N}$-lannoitustasolla perunoiden nitraattipitoisuus oli korkeampi kuin lannoittamattomien tai pienimmällă $\mathrm{N}$-lannoituksella tuotettujen perunoiden. $\mathrm{P}$ - ja $\mathrm{K}$-lannoitus vaikuttivat tässä kokeessa ratkaisevasti sadon mäărảăn mutta poikkeuksellisesti eivăt sen laatuun. Maan K-tilan ylläpito kolme vuotta jatkuneessa yhtämittaisessa perunanviljelyssä osoittautui vaikeaksi. 